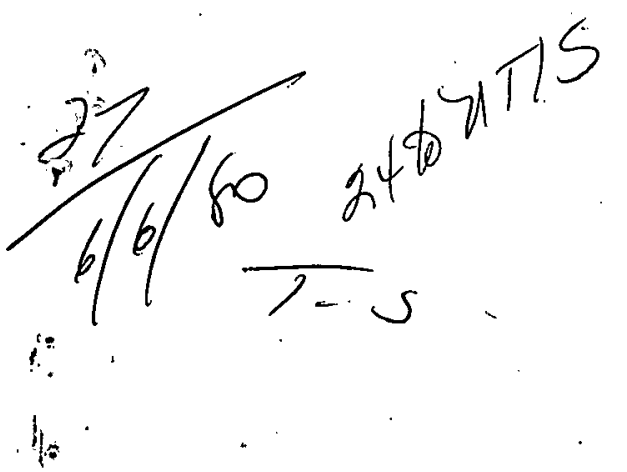

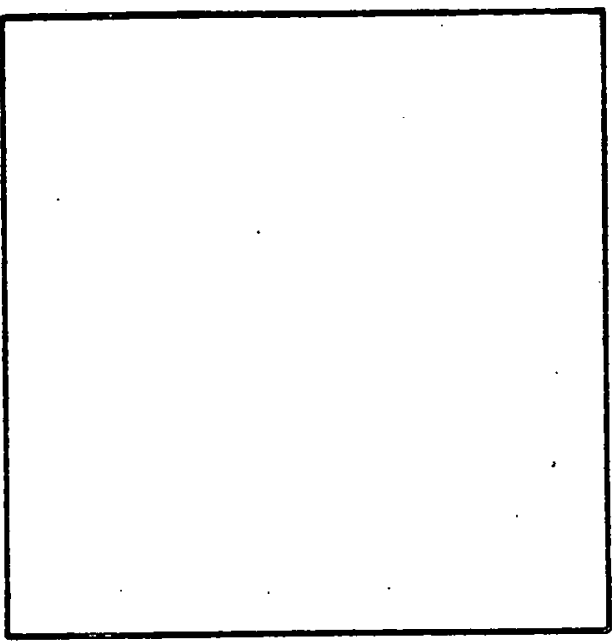

BDX-613-2399

\title{
Stress Relaxation of Cellular - Silicone Material
}

\section{MASTER}

By J. W. Schneider

Published May 1980

Topical Report

?

Prepared for the United States Department of Energy Under Contract Number DE-ACO4-76-DPO0613. 


\section{DISCLAIMER}

This report was prepared as an account of work sponsored by an agency of the United States Government. Neither the United States Government nor any agency Thereof, nor any of their employees, makes any warranty, express or implied, or assumes any legal liability or responsibility for the accuracy, completeness, or usefulness of any information, apparatus, product, or process disclosed, or represents that its use would not infringe privately owned rights. Reference herein to any specific commercial product, process, or service by trade name, trademark, manufacturer, or otherwise does not necessarily constitute or imply its endorsement, recommendation, or favoring by the United States Government or any agency thereof. The views and opinions of authors expressed herein do not necessarily state or reflect those of the United States Government or any agency thereof. 


\section{DISCLAIMER}

Portions of this document may be illegible in electronic image products. Images are produced from the best available original document. 
This report was prepared as an account of work sponsored by the United States Government. Neither the United States nor the United States Department of Energy, nor any of their employees, nor any of their contractors, subcontractors, or their employees, makes any warranty, express or implied, or assumes any legal liability or responsibility for the accuracy, completeness or usefulness of any information, apparatus, product or process disclosed, or represents that its use would not infringe privately owned rights.

Printed in the United States of America

Available From the National Technical Information Service, U.S. Department of Commerce, 5285 Port Royal Road, Springfield, Virginia 22161.

Price: $\quad$ Microfiche $\$ 3.00$

Paper Copy $\$ 4.00$ 
$\mathrm{BDX}-613-2399$

Distribution Category UC-25

\section{STRESS RELAXATION OF CELLULAR}

SILICONE MATERIAL

By J. W. Schneider

Published May 1980

Topical Report

J. W. Schneider, Project Leader

$$
\text { DISCLAIMER }
$$

This book was prepared as an account of work sponsored by an ogency of the United States Government. Neither the United States Government nor any agency thereof. nor any of their employees, makes an warranty. express or implied, or assumes any legal liability or responsin

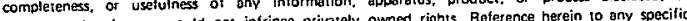
represents that its use would nol in commercial product, process, or seplice oy endrsement. recommendation, or fevoring by the United 


\section{STRESS RELAXATION OF CELLULAR SILICONE MATERIAL}

BDX-613-2399, Topical Report, Published May 1980

Prepared by J. W. Schneider

The long-term (10 years) stress relaxation properties of cellular silicone materials at room temperature are being evaluated. The cellular structure is formed by using urea as a leachable filler. Both equilibrium (random copolymer) and condensation (block copolymer) type base polymers are included. Each material was compounded to yield two different densities for several thickness combinations. These density-thickness combinations then were compressed to nominal compressions of 20 and 40 percent with nine replicates at each condition. Five are tested regularly, two are 3 year controls, and two are 10 year controls. A speciallydesigned fixture is used to maintain a specific compression on the cellular sample, and a universal test machine is used to acquire the load data. The load was recorded at initial assembly and at selected times thereafter. The present data have been generated for equilibrium-type materials stored 4 years and condensation-type materials stored 3 years.

fa-evc

This report was prepared as an account of work-sponsored by the United States Government. Neither the United States, nor the United States Department of Energy, nor any of their employees. nor any of their contractors, subcontractors, or their employees, makes any warranty, expressed or implied or assumes any legal liability or responsibility for the accuracy, completeness or usefulness of any information, apparatus, product, or process disclosed, or represents that its use would not infringe privately owned rights.
The Bendix Corporation Kansas City Division P. O. Box 1159 Kansas City, Missouri 64141

A prime contractor with the United States Department of Energy under Contract Number DE-AC04-76-DP00613 


\section{CONTENTS}

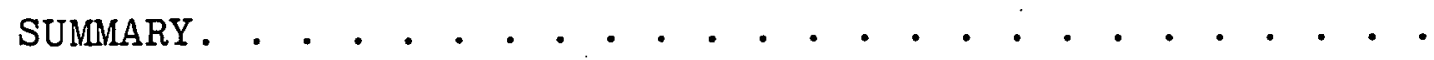

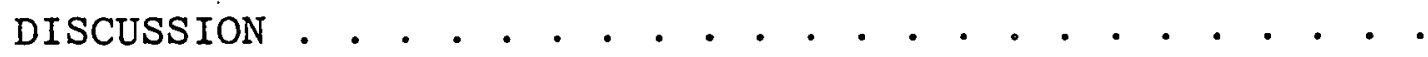

SCOPE AND PURPOSE. . . . . . . . . . . . . . . . . . . . . 6

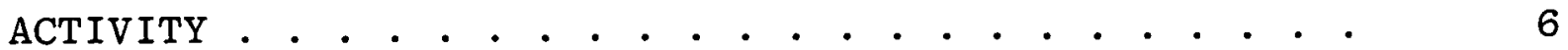

ACCOMPLISHMENTS . . . . . . . . . . . . . . . . . . . 9

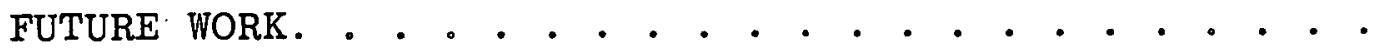




\section{ILLUSTRATIONS}

\section{Figure}

Page

1

Compression Fixture for Aging of Material. .

Typical Loading and Unloading Curves, Normal Scale, at Zero and 3 Years Time . . .

Typical Loading and Unloading Curves, Expanded Scale With Tangent Drawn, at Zero and 3 Years Time. . . . . . . . .

Percent Retention Versus Log Time for Equilibrium Type Material, $0.34 \mathrm{~g} / \mathrm{cm}^{3}$ Nominal Density. . . . . . . . . . . .

Percent Retention Versus Log Time for Condensation Type Material, $0.34 \mathrm{~g} / \mathrm{cm}^{3}$ Nominal Density. . . . . . . . . . . . . .

Percent Retention Versus Log Time for Equilibrium Type Material, $0.52 \mathrm{~g} / \mathrm{cm}^{3}$ Nominal Density. . . . . . . . . . . . .

Percent Retention Versus Log Time for Condensation Type Material, $0.52 \mathrm{~g} / \mathrm{cm}^{3}$ Nominal Density. . . . . . . . . . . . .

Percent Retention Versus Log Time, Comparison of Materials . . . . . . . . . . . .

Percent Retention Versus Log Time for Condensation Type Material, $0.34 \mathrm{~g} / \mathrm{cm}^{3}$

Nominal Density With 3-Year Control Samples. . . . . . . . . . . . . 


\section{SUMMARY}

Bendix Kansas City is gathering stress relaxation information for cellular silicone materials that are formed with urea leachable filler. Two types of base polymers are used in the test: equilibrium type (random copolymer) and condensation type (block copolymer). Each of these was compounded to provide finished materials with nominal apparent densities of 0.34 and $0.52 \mathrm{~g} / \mathrm{cm}^{3}$. Three sample variations of $1.17,1.52$, and $2.54 \mathrm{~mm}$ nominal thickness were prepared from the lower density product, and two sample variations of 1.52 and $2.54 \mathrm{~mm}$ nominal thickness were prepared from the higher density product. Each of the material/thickness combinations was compressed to nominal compressions of 20 and 40 percent, with nine replicates at each condition.

A specially designed compression fixture for aging is used to maintain a specific compression on the cellular sample at room temperature, and a universal test machine is used to acquire the load data. The load was recorded at initial assembly and at selected times thereafter. In all, a total of 180 specimens are in test, 90 equilibrium type material samples that have been stored 4 years and 90 condensation type material samples that have been stored for 3 years. Each condition for each material type has nine replicates. Of these nine samples, two are 3 year controls, two more are 10 year controls, and five are tested regularly.

The current data still support the statement that the time dependent loss of load bearing properties is approximately log-linear, with the major differences found to be between the material types and between the two densities of each material type. Extrapolation indicates that at the end of the planned 10-year study, the load retention of all samples will be between 58 and 68 percent of original; the condensation type material is expected to be superior. 


\section{DISCUSSION}

SCOPE AND PURPOSE

Cellular silicone materials act as gap fillers to allow for space left from manufacturing tolerances and thermal expansion of adjacent components. These materials are required to exert a specific compressive force at predetermined maximum and minimum gaps. The purpose of this project is to gather information about the long term stress behavior of the material under load.

\section{ACTIVITY}

The aging fixtures used in this study are compatible with a universal test machine. Each sample is aged in its own fixture (Figure 1). With the fixture installed on the test machine, the load bearing properties of the material can be checked at selected time intervals. The assembled aging fixture seen on the left side in Figure 1 has a threaded stud that screws into the actuator rod of the test machine. The six nuts and bolts also seen in this view maintain the clamping force on the sample while aging. Also, the four cap screws in this view hold a removable detail (plug) that can be changed to vary the amount of compression placed on the sample. This cavity and sample can be seen in the right hand view of Figure 1 .

A total of 180 specimens are in test: 90 equilibrium type (random copolymer) samples (material in use now) that have been stored 4 years, and 90 condensation type (block copolymer) samples (material for future use) that have been stored 3 years. Each type of material was compounded to yield nominal apparent densities of 0.34 and $0.52 \mathrm{~g} / \mathrm{cm}^{3}$. Three sample variations of $1.17,1.52$, and $2.54 \mathrm{~mm}$ nominal thickness were prepared from the lower density product, and two sample variations of 1.52 and $2.54 \mathrm{~mm}$ nominal thickness were prepared from the higher density product. Each of the material/thickness combinations was compressed to nominal compression of 20 and 40 percent. There are nine replicates at each condition; five are tested regularly, and four are control samples.

The initial procedure for testing was to place the lower half (stud side) of the fixture into the load frame and place a 50.8-mm-diameter sample in the center of the cavity. The remaining half of the fixture is aligned and set on the sample. A small controlled amount of preload is applied to maintain contact between the fixture and the test machine load cell. Force is the feedback variable in this test; increasing force on the fixture is applied at a constant rate up to and beyond fixture closure. 

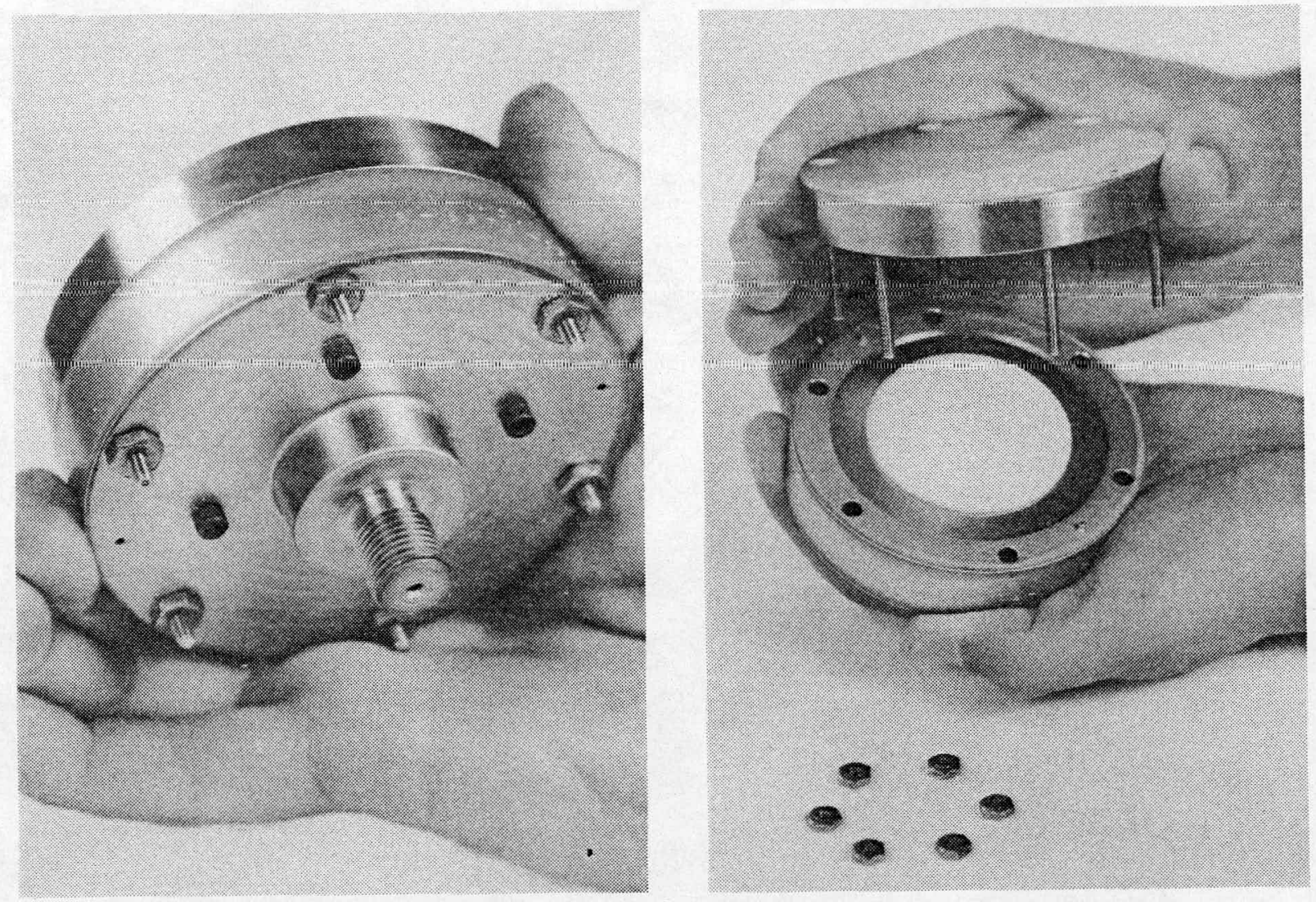

Figure 1. Compression Fixture for Aging of Material

At this point, the loading is reversed until the preload is the only force, and the unloading is reversed to return the fixture well beyond fixture closure. Then, the unloading-loading sequence is repeated. Holding the load at this point, the six retaining nuts are placed back on the fixture to maintain this compression on the sample until the sample is checked again. The fixture is then removed, and a new fixture can be assembled. Typical results from the initial assembly testing are shown in the upper set of curves in Figure 2 .

The lower set of curves in Figure 2 is a typical result of later testing. The testing sequence in this case is identical to that of the assembly steps with the exception of the starting point. Assembled fixtures are placed in the load frame and a force greater than the closing force is applied. The six retaining nuts are loosened and removed and the test continues in the same manner as before. The sample is cycled three times and then is locked up until the next testing. 


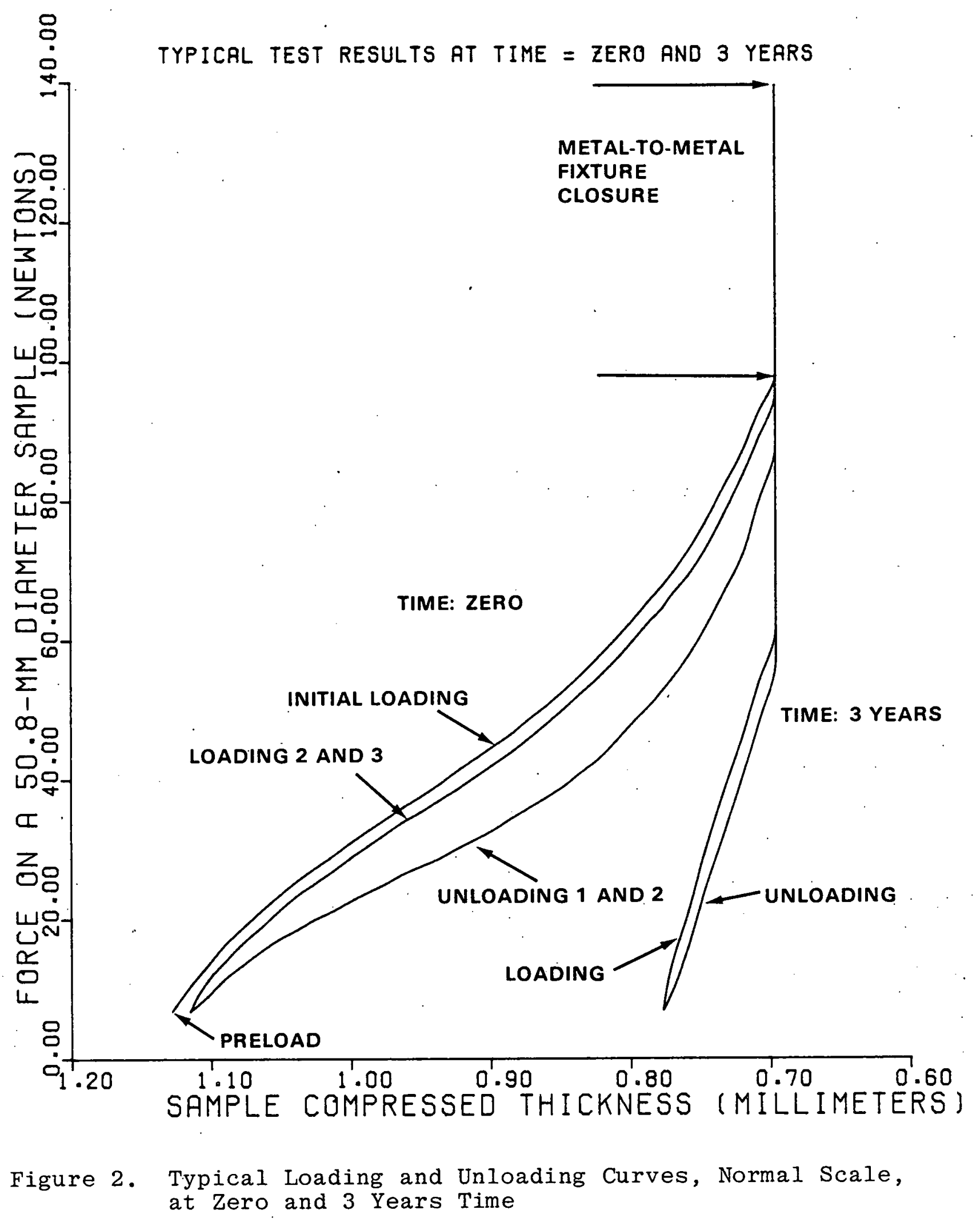


Two pieces of information are available from the two sets of curves. One is the force exerted by the sample at fixture closing, and the second is the thickness of the sample at minimum load (preload).

Figure 2 shows that determining the closure load with any precision is difficult. For this reason, the actual measurement is obtained by using an amplified displacement scale (Figure 3 ). As before, the upper curve is the assembly loading and the lower set the aged loading. To determine the closure load, a line tangent to the loading curve, between 0.025 and $0.0025 \mathrm{~mm}$ prior to closure, is drawn and its intersection with the vertical closure line is read. By dividing the value obtained for the aged sample by the value obtained for the initial assembly load, a percent retention can be calculated. These data are plotted versus the $\mathrm{log}$ of the time in assembly, as shown in Figures 4 through 7. All the data points were used to determine a single straight line approximation, by the method of least squares, for each material type and each density. The results of the previous test are shown by the dashed line. These curves all are plotted together in Figure 8 . The 3-year control samples were substituted for the 3-year data to determine how well these samples compare with the regularly-tested samples at the 3 -year period (Figure 9 ).

Compressed thickness measurements at the minimum load were. recorded as a side benefit. The measured values of the aged samples were compared to the values at assembly and, by means of standard compression set calculations, to a value called effective compression set. These data are plotted versus the time in assembly and shown in Figure 10. The dashed lines are the results of substituting the 3-year control-samples for the regularlytested samples at 3 years.

The points of the 3-year control samples versus the regularly tested samples are shown in Figure 9. The solid line is the result of a least square fit for data up to now. The dash line is a least square fit for substituted 3-year control samples. This shift in distance of the dashed and solid lines is the worst of all cases. With this in mind, the control samples seem to be in accord with the regularly tested samples for load deflection. Looking at the scatter of control sample points shown in Figure 10, the meaning of the effective compression set results is dubious.

\section{ACCOMPLISHMENTS}

The rate of load loss for both densities and types of material is approximately the same. At the end of the 10-year time, the 


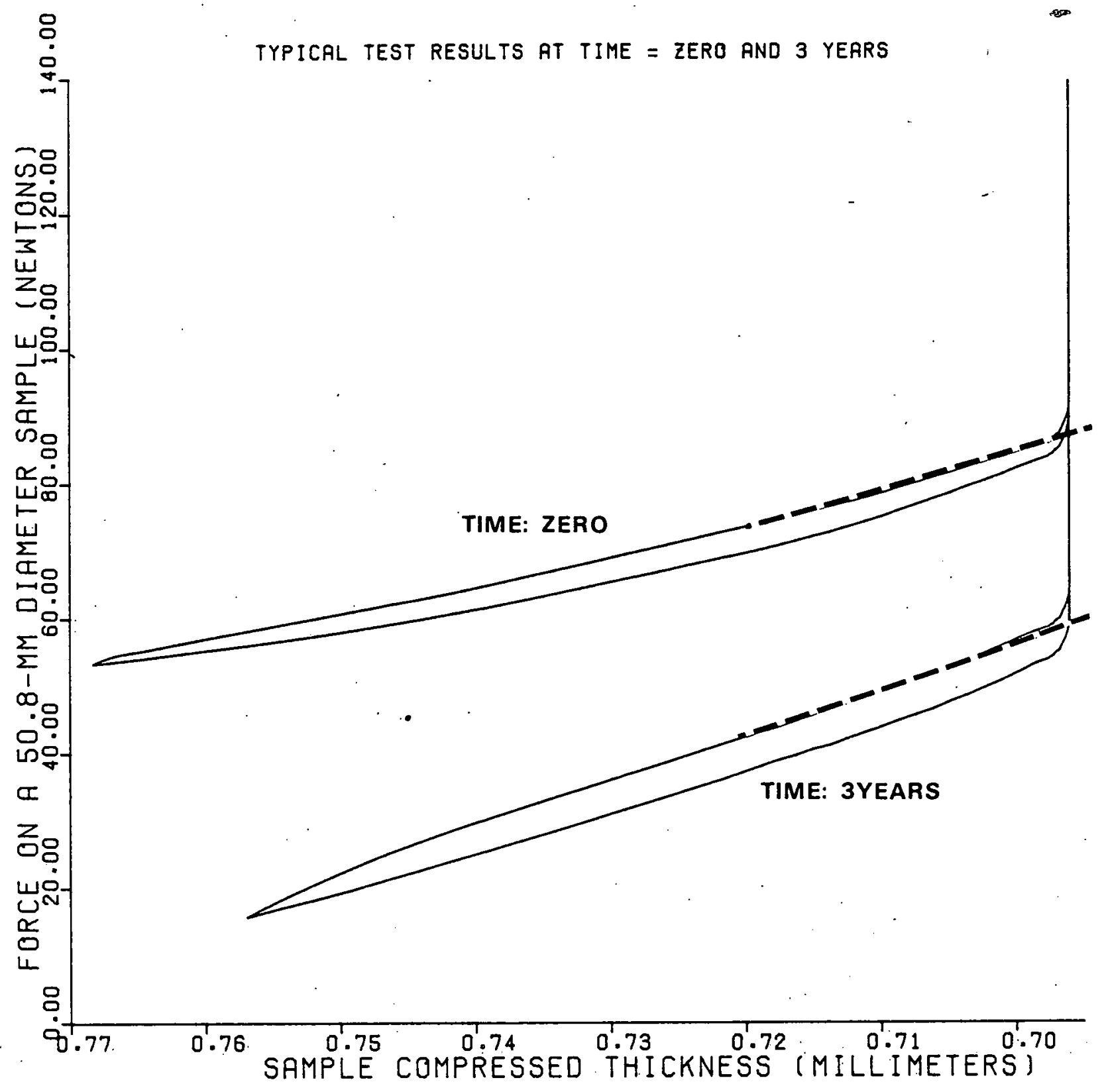

Figure 3. Typical Loading and Unloading Curves, Expanded Scale With Tangent Drawn, at Zero and 3 Years Time

percent retention of load will be between 58 and 68 percent of original load, with the condensation type material having a higher load retention value. The condensation type material is also the lower effective compression set material. 


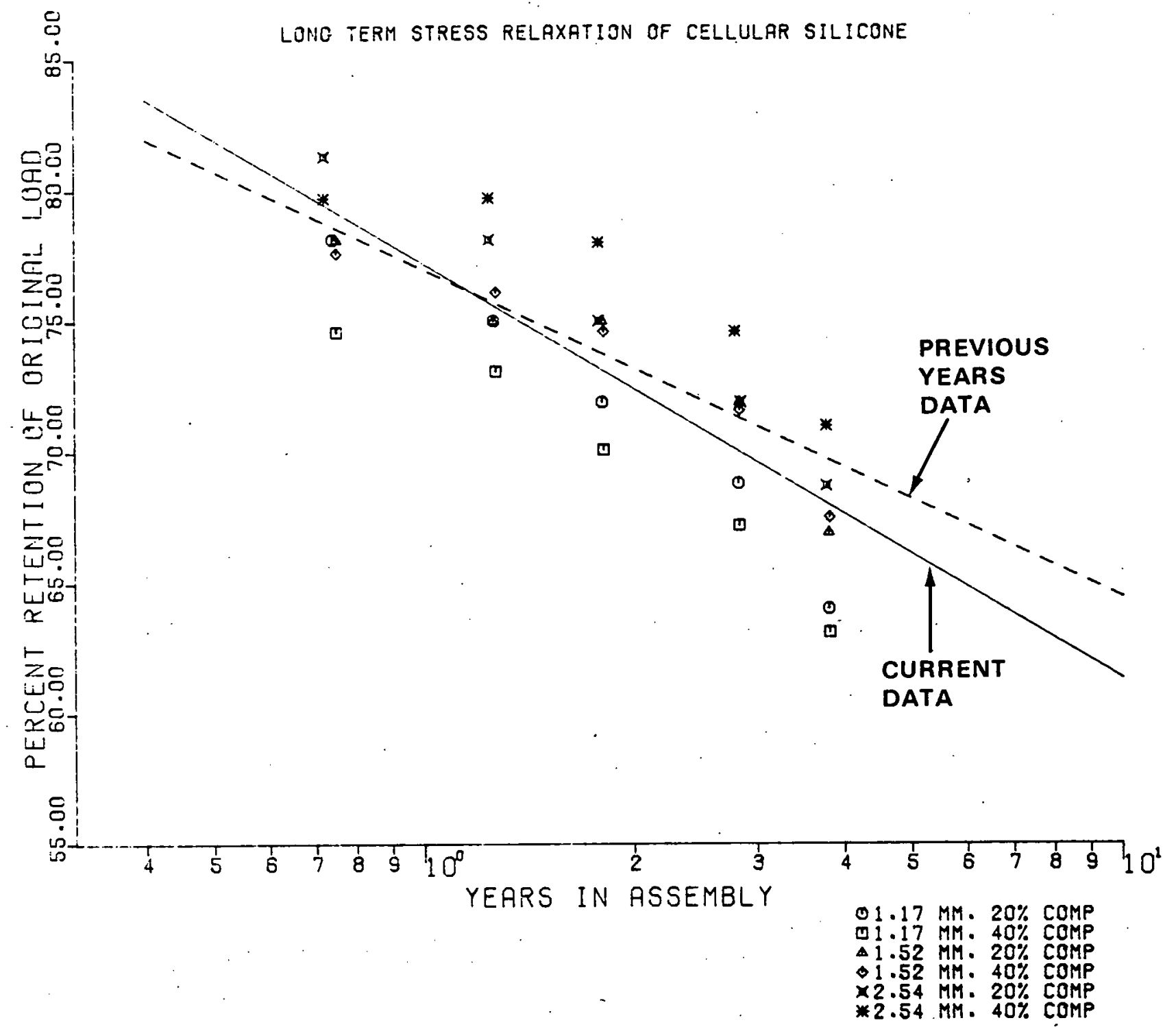

Figure 4. Percent Retention Versus Log Time for Equilibrium Type Material, $0.34 \mathrm{~g} / \mathrm{cm}^{3}$ Nominal Density

FUTURE WORK

The samples will continue to be monitored regularly until the completion of the 10 -year plan. A new material, $0.64 \mathrm{~g} / \mathrm{cm}^{3}$ nominal density condensation type, may be added to the study. 


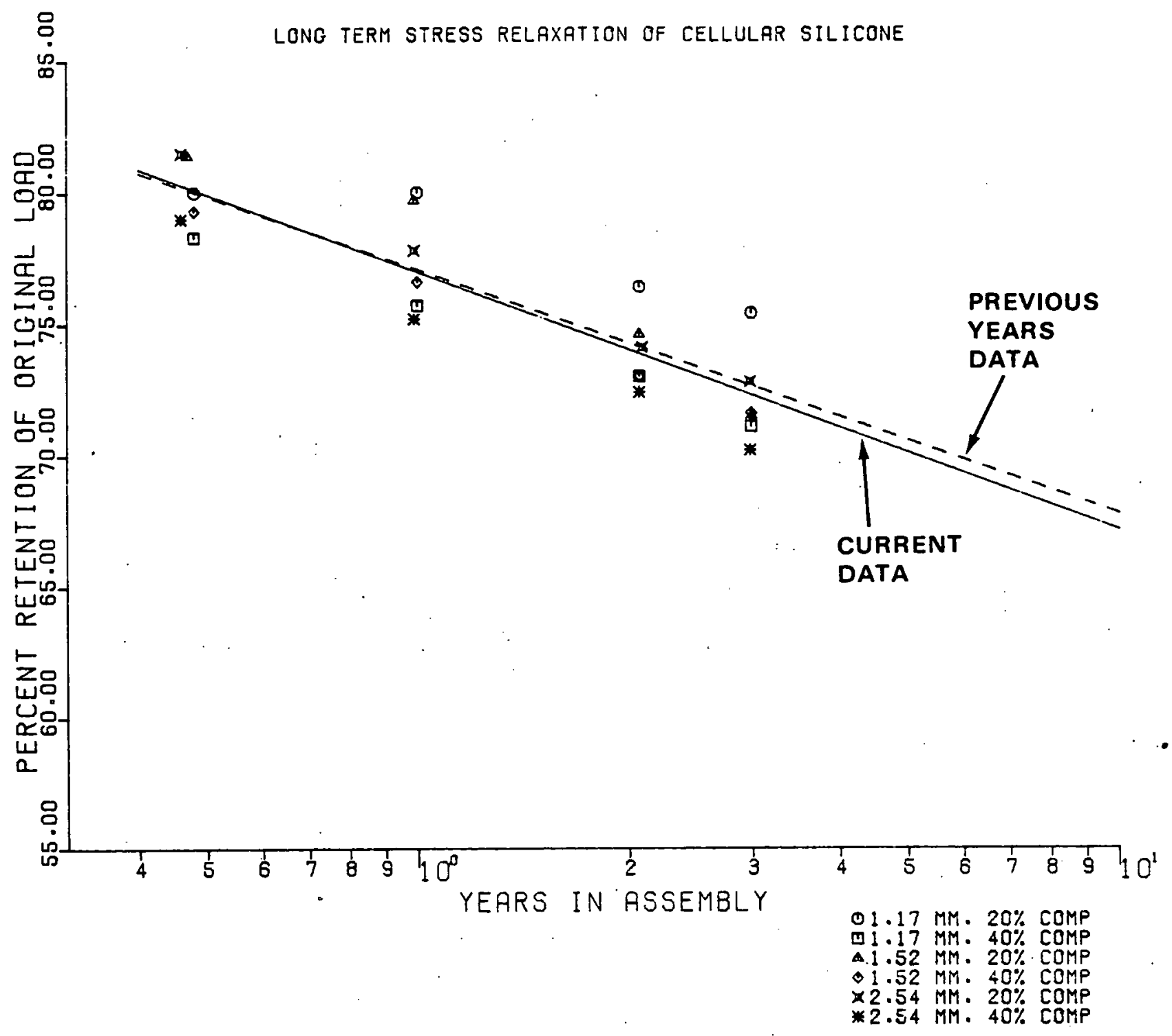

Figure 5. Percent Retention Versus Log Time for Condensation Type Material, $0.34 \mathrm{~g} / \mathrm{cm}^{3}$ Nominal Density 


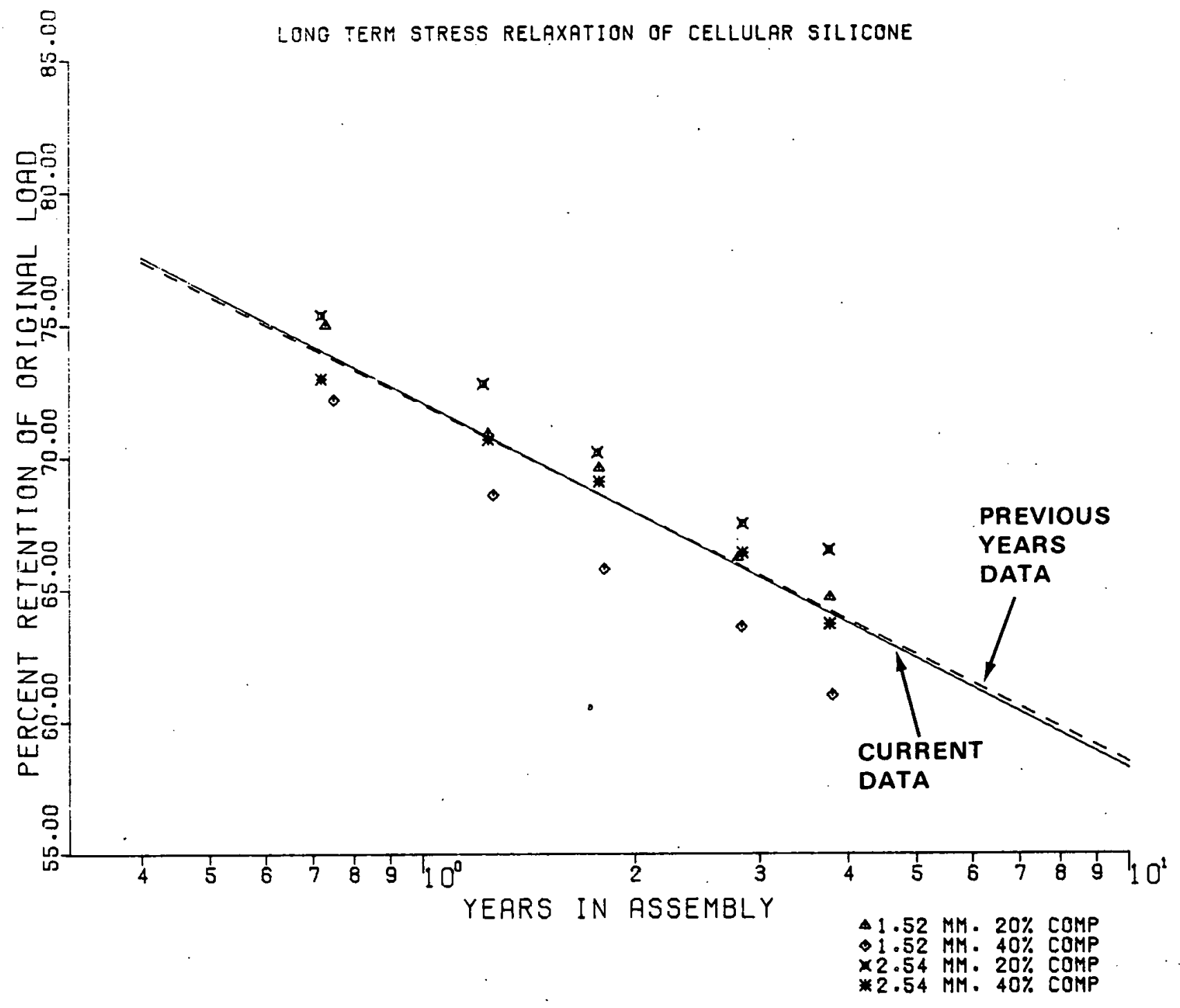

Figure 6. Percent Retention Versus Log Time for Equilibrium Type Material, $0.52 \mathrm{~g} / \mathrm{cm}^{3}$ Nominal Density 


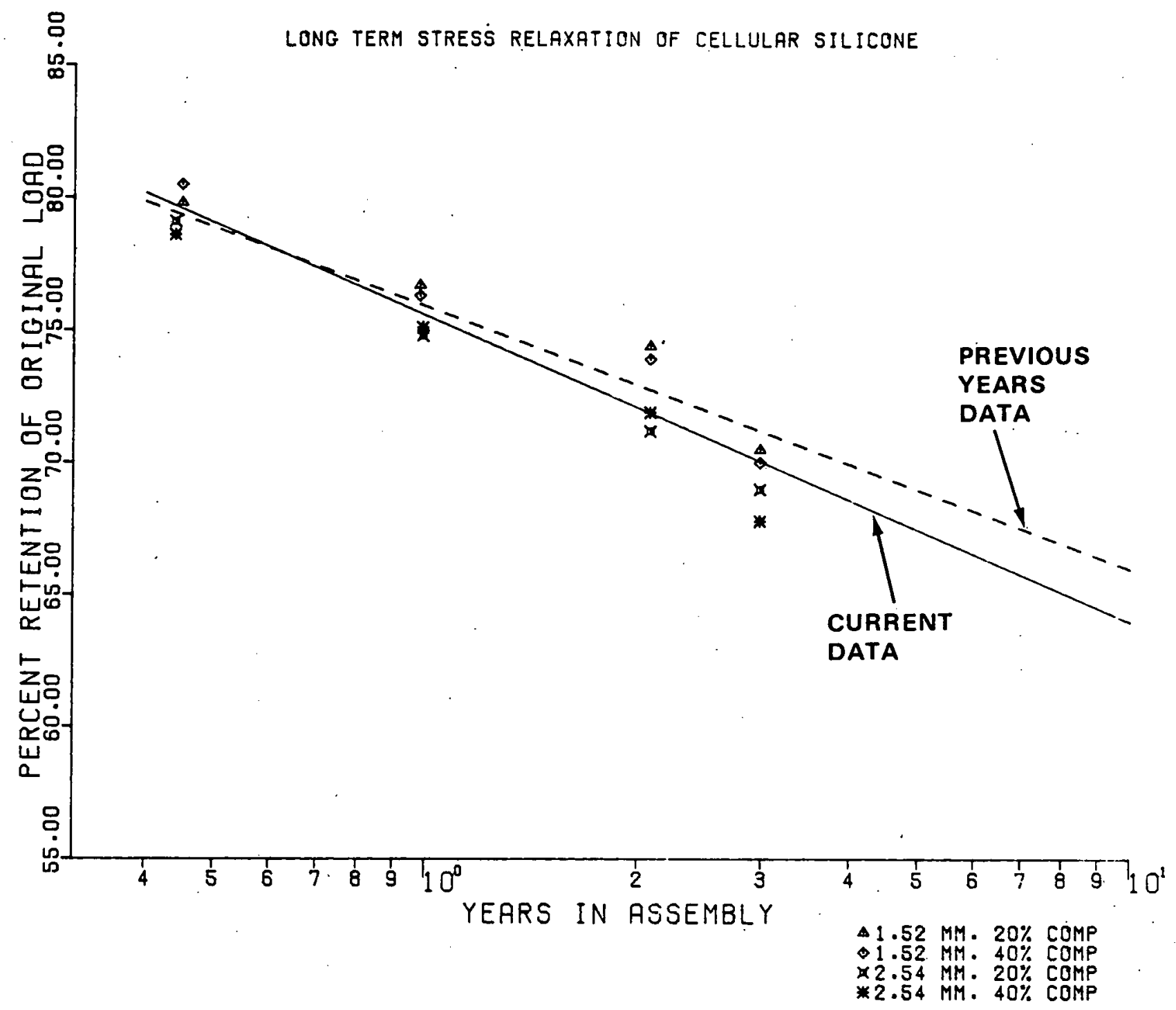

Figure 7. Percent Retention Versus Log Time for Condensation Type Material, $0.52 \mathrm{~g} / \mathrm{cm}^{3}$ Nominal Density 


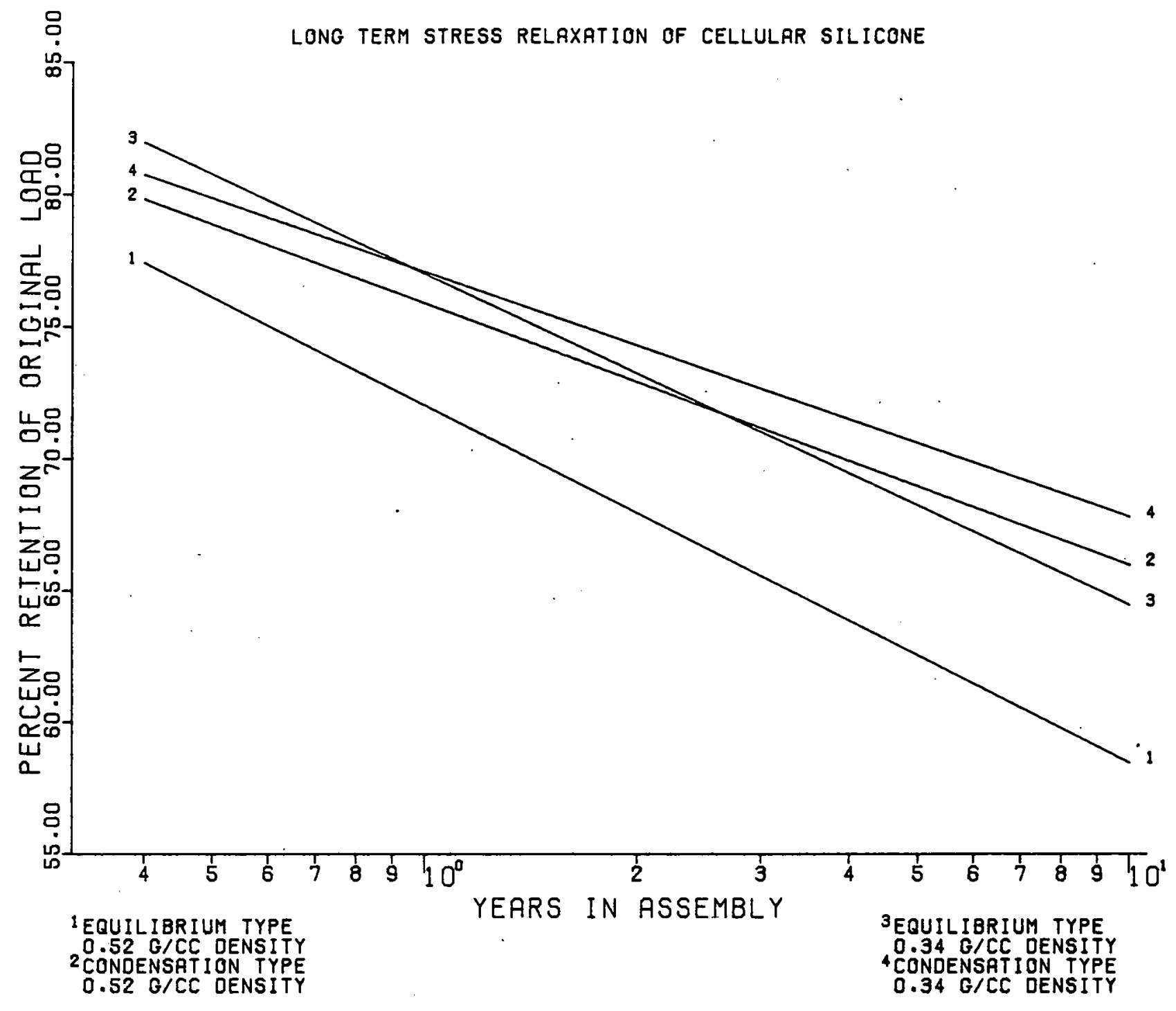

Figure 8. Percent Retention Versus Log Time, Comparison of Materials 


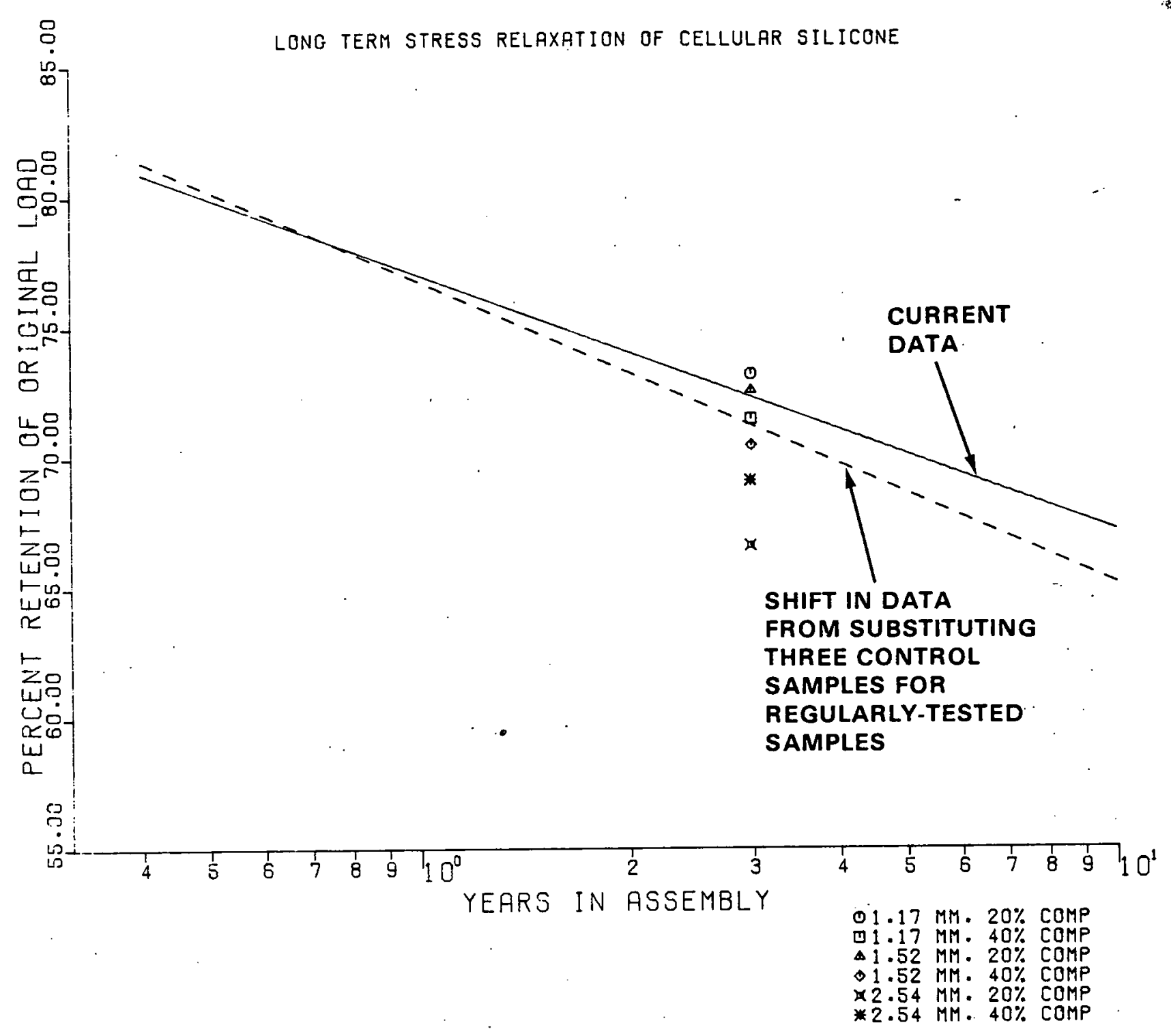

Figure 9. Percent Retention Versus Log Time for Condensation Type Material, $0.34 \mathrm{~g} / \mathrm{cm}^{3}$ Nominal Density With 3-Year Control Samples 


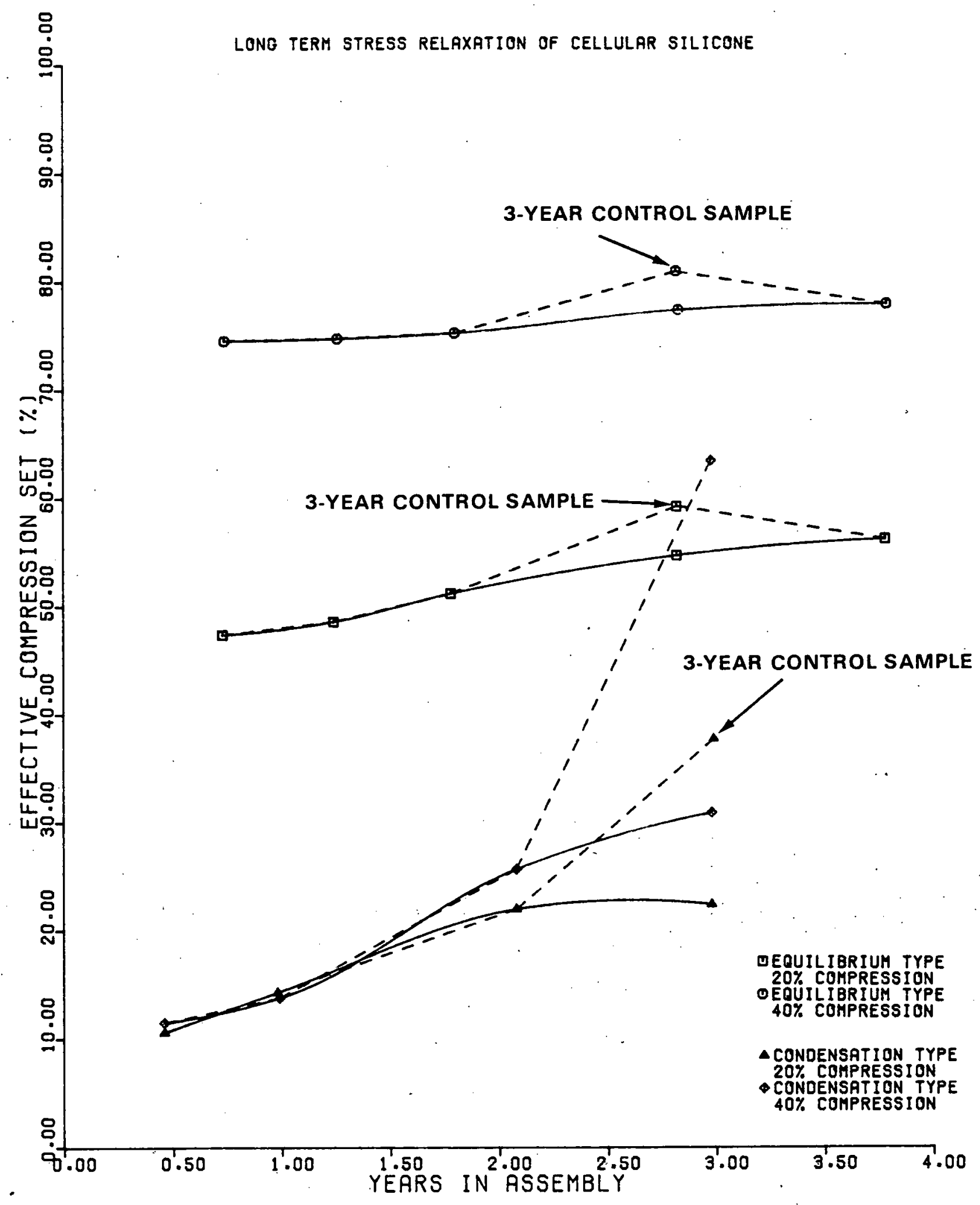

Figure 10. Effective Compression Set Versus Aging Time 


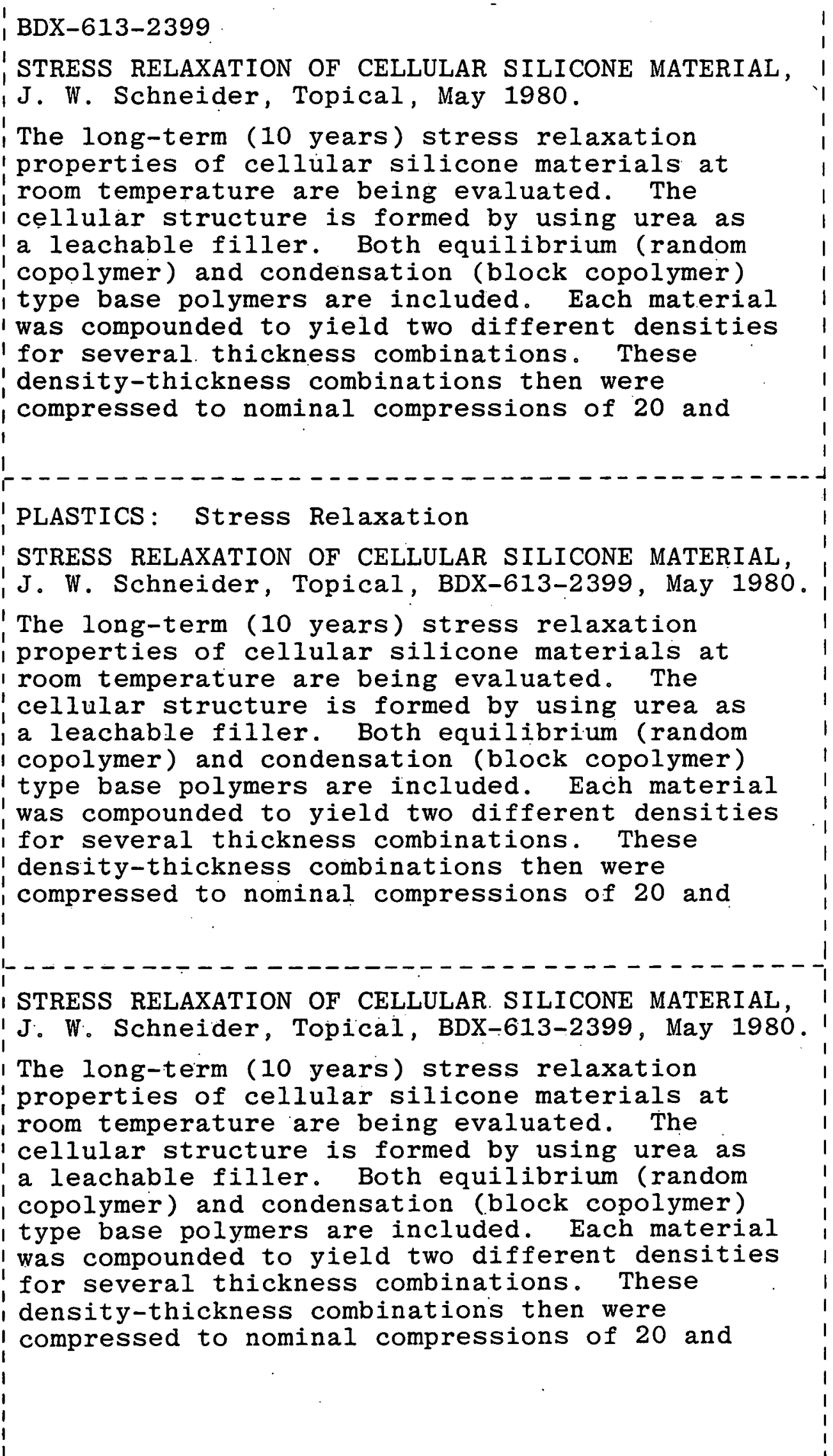


40 percent with nine replicates at each condition. Five are tested regularly, two are 3 year controls, and two are 10 year controls. A specially-designed fixture is used to maintain a specific compression on the cellular sample, and a universal test machine is used to acquire the load data. The load was recorded at initial assembly and at selected times thereafter. The present data have been generated for equilibrium-type materials stored 4 years and condensationtype materials stored. 3 years.

40 percent with nine replicates at each condition. Five are tested regularly, two are 3 year controls, and two are 10 year controls. A specially-designed fixture is used to maintain a specific compression on the cellular sample, and a universal test machine is used to acquire the load data. The load was recorded at initial assembly and at selected times thereafter. The present data have been generated for equilibrium-type materials stored 4 years and condensationtype materials stored 3 years.

40 percent with nine replicates at each condition. Five are tested regularly, two are 3 year controls, and two are 10 year controls. A specially-designed fixture is used to maintain a specific compression on the cellular sample, and a universal test machine is used to acquire the load data. The load was recorded at initial assembly and at selected times thereafter. The present data have been generated for equilibrium-type materials stored 4 years and condensationtype materials stored. 3 years. 